\title{
Vertical structure of very nearshore larval fish assemblages in a temperate rocky coast
}

\author{
Rita Borges • Ricardo Beldade • Emanuel J. Gonçalves
}

Received: 2 January 2006 / Accepted: 24 November 2006 / Published online: 16 December 2006

(C) Springer-Verlag 2006

\begin{abstract}
Small-scale vertical patterns of larval distribution were studied at a very nearshore larval fish assemblage, during the spring-summer period of several years, at two depth strata (surface and bottom) using sub-surface and bottom trawls. A total of 4,589 larvae (2,016 from surface samples and 2,573 from bottom samples) belonging to 62 taxa included in 22 families were collected. Most larvae belonged to coastal species. Although inter-annual variations in larval density and diversity could be found, total larval abundance was always higher near the bottom whereas diversity was higher at the surface. A marked distinction between the structure of surface and bottom assemblages was found. Sixteen taxa explained $95 \%$ of the similarity among surface samples. Larvae which contributed most to this similarity included species like clupeiformes, sparids and serranids, and also blenniids, tripterygiids and some labrids. In the bottom samples, fewer species were present, with only six taxa, almost exclusively from species which lay demersal eggs, contributing to $95 \%$ of the similarity between samples. Larvae present at the surface were significantly smaller than at the bottom. For some of the most abundant species found at the bottom, only small larvae occurred at the surface while the whole range of sizes was present at the bottom, indicating that larvae may be completing the entire pelagic phase near the adults'
\end{abstract}

Communicated by S.A. Poulet, Roscoff.

R. Borges $\cdot$ R. Beldade $\cdot$ E. J. Gonçalves $(\bowtie)$

Eco-Ethology Research Unit,

Instituto Superior de Psicologia Aplicada,

R. Jardim do Tabaco 34, 1149-041 Lisbon, Portugal

e-mail: emanuel@ispa.pt habitat. These results indicate that larval retention near the reefs probably occurs for these species, although for others dispersal seems to be the prevailing mechanism.

\section{Introduction}

Traditional sampling methods for ichthyoplankton studies are difficult to use in nearshore waters due to shallower depths, complex bottom topography (Smith et al. 1987) and wave action. This resulted in a poorer knowledge of coastal ichthyoplankton communities and their distribution patterns at small spatial scales. Several studies on nearshore larval assemblage composition and spatial distribution patterns have, however, been conducted in recent years on coral reefs (Smith et al. 1987; Kobayashi 1989; Boehlert and Mundy 1993; Leis 1993; Sponaugle and Cowen 1996; Kingsford and Finn 1997; Hendriks et al. 2001; Kingsford 2001; Wilson 2001; Sponaugle et al. 2003). In these environments, evidence is growing on the ability of larvae to actively modify their position in the water column which can result in larval retention in the vicinity of the reefs (Leis 1991a, b; Jones et al. 1999, 2005; Swearer et al. 1999, 2002; Cowen 2002; Leis and McCormick 2002; Sponaugle et al. 2002; Taylor and Hellberg 2003; Paris and Cowen 2004). Depth stratified sampling with plankton nets and light traps used in shallow waters directly over reefs (Doherty and Carleton 1997; Fisher and Bellwood 2002a; Fisher 2004; Hendriks et al. 2001; reviewed by Cowen 2002 and Leis and McCormick 2002) identified vertical distribution patterns, sometimes with a clear daily or ontogenetic basis (Leis 1986a, 1991a, b, 1993; Sponaugle and Cowen 1996; 
Sponaugle et al. 2003; Leis et al. 2006). In situ behavioural studies also revealed species-specific behaviours and showed that larvae of coral reef fish exhibit directional swimming capabilities and regulate their vertical position at a fine scale (Leis and Carson-Ewart 1999, 2000a; Leis and McCormick 2002; Leis 2004, 2006; Leis et al. 2006).

In temperate regions, extensive work has been done on ichthyoplankton composition and vertical distribution in oceanic or shelf waters (e.g. Kendall and Naplin 1981; Southward and Barret 1983; McGowen 1993; Moser and Smith 1993; Conway et al. 1997; Olivar and Sabatés 1997; Gray 1998; Somarakis et al. 2002; Sabatés 2004). Some studies showed evidence of vertical migration patterns for some species (for a review see Neilson and Perry 1990).

However, in nearshore waters little is known about the spatial distribution of fish larvae. Some studies on micro-scale distribution of larval fish have focused on only one species. Marliave (1981) found vertical migration patterns in Gibertidia sigalutes (Cottiidae) larvae within the first $3 \mathrm{~m}$ layer, in Vancouver Island. Jenkins et al. (1998, 1999) reported diurnal vertical migrations of Sillaginodes punctata (Sillaginidae) in nearshore waters. Breitburg (1989) studied in situ behaviour of Gobiosoma bosci (Gobiidae) in an oyster reef and suggested that pre-settlement schooling may be a common behaviour among temperate benthic fish species. Breitburg et al. (1995) performed field studies to examine the relationship between these aggregations and water flow and suggested that larvae actively respond to water flow patterns near reefs and that this may be determinant to understand the fine scale spatial patterns of distribution at settlement.

Differences in larval assemblages between inshore and offshore samples and, in some occasions, depth stratified patterns of distribution have been described by several authors (Boehlert et al. 1985; Cowen et al. 1993; McGowen 1993; Tilney et al. 1996; Gray and Miskiewicz 2000). Brewer and Kleppel (1986) suggested that vertical patterns of neritic fish larvae could contribute to their retention in nearshore waters. Marliave (1986) sampled the extreme nearshore over rocky reefs and found that larvae of intertidal fishes occurred more frequently along rocky shores than in adjacent sandy beaches. This author suggested that intertidal fish larvae are capable of resisting offshore and alongshore dispersal and may prefer more turbulent waters or avoid more laminar velocity gradients along sand or mud shores. Tilney et al. (1996) also suggested larval retention nearshore for some rock associated species present in the Tsitsikamma National Park Marine Reserve, South Africa.
More recently, Sabatés et al. (2003) found differences in patterns of larval distribution among species from a nearshore rocky fish assemblage in the northwest Mediterranean. Also, Vélez et al. (2005) described distinct vertical assemblages of nearshore fish larvae at Independencia Bay, Peru. These authors compared the larval composition at the surface and at $10 \mathrm{~m}$ depth and found that these assemblages were distinct even though a strong vertical mixing was present. However, the bottom assemblages were not sampled (the bottom at the sampling stations was at $22-25 \mathrm{~m}$ ). For several species of this inshore assemblage, larvae were present at different developmental stages, suggesting retention in nearshore waters.

In this paper we describe the nearshore larval assemblages present at the Arrábida Marine Park (west coast of Portugal) where we have observed dense schools of larvae near the reefs at shallow depths (less than $15 \mathrm{~m}$ ) during SCUBA diving. Our aims are (1) to investigate the composition of the coastal larval fish assemblages present during the spring-summer period; (2) to compare the structure of the assemblage and larval density at the surface and bottom depth strata; (3) to search for possible ontogenetic vertical distribution patterns.

\section{Materials and methods}

\section{Study area}

This study was carried out at the Arrábida Marine Park, between Sesimbra and Portinho da Arrábida, $30 \mathrm{~km}$ South of Lisbon $\left(9^{\circ} 00^{\prime} 15^{\prime \prime}-9^{\circ} 03^{\prime} 48^{\prime \prime} \mathrm{W}\right.$ and $38^{\circ} 26^{\prime}-38^{\circ} 27^{\prime} \mathrm{N}$ ) (Fig. 1). Although located on the Portuguese west coast, the study site faces south, being protected from the prevailing north and north-west winds and waves. Relatively calm sea conditions exist throughout the year, allowing sampling in the very nearshore where wave action is negligible. Tidal currents parallel to the shoreline prevail. The nearby Sado estuary has little influence over this coastal area, given that during the spring and summer months the water flow is very reduced (Martins et al. 2002). The adjacent mountain chain of Arrábida is characterized by high vertical calcareous cliffs. Boulders of many different sizes, resulting from the disintegration of these cliffs, originate a highly heterogeneous rocky subtidal habitat where many benthic fish species occur (Gonçalves et al. 2003). In the extreme nearshore, the rocky sub-stratum extends offshore only for some tens of metres and depths are very shallow (maximum around $13 \mathrm{~m}$ ). 
Fig. 1 Study site location on the Portuguese west coast
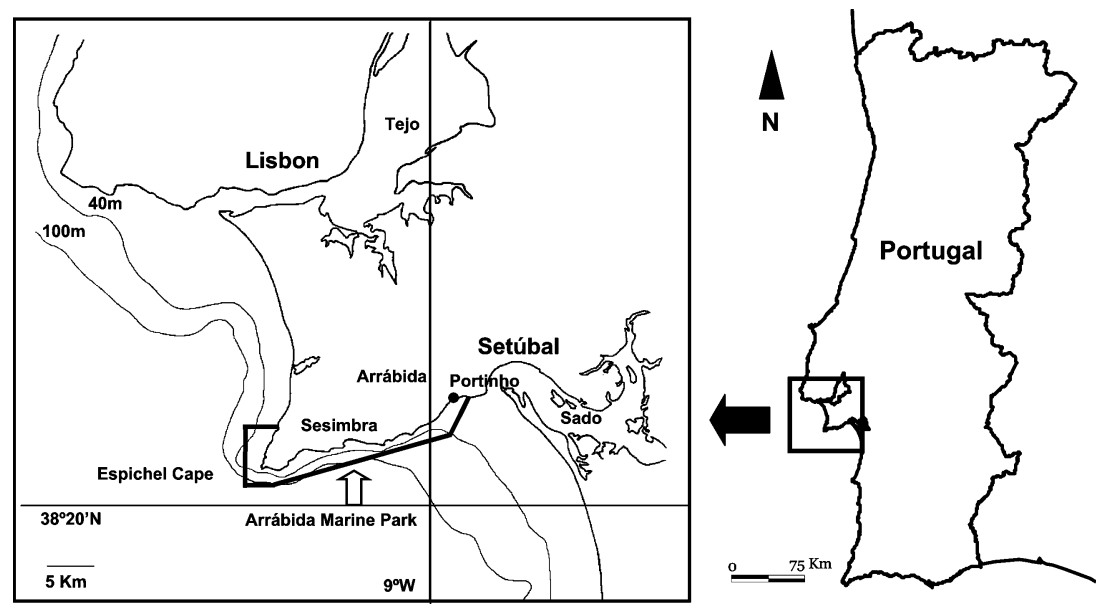

Sampling procedure

Sampling was performed in the extreme nearshore (less than $50 \mathrm{~m}$ from shore) in the spring-summer period, when most coastal fish species breed. The surface larval assemblage was sampled in 1999 and 2000 with sub-superficial trawls, at 17 stations distributed along the study area (Table 1 ). The bottom assemblage was sampled at two locations in 2001 and 2002. In 2003, both depth strata were sampled (Table 1). Bottom sampling was performed along 14 days in 2001, 15 days in 2002 and 6 days in 2003, with an average of four dives per day. Surface samples were taken monthly, with a mean number of samples between nine (in 2003) and 12 (in 1999), taken in 1 or 2 days. Owing to logistic constraints, all samples were taken during the day, between 9 and $18 \mathrm{~h}$, and at all tidal phases. All samples collected at each depth were considered as replicates since no longitudinal gradients in assemblage structure were found (unpublished results).

Surface samples consisted of 5-min sub-superficial (1 $\mathrm{m}$ depth) trawls using a standard plankton net with a $350 \mu \mathrm{m}$ mesh size, $0.30 \mathrm{~m}$ mouth diameter and a mouth diameter:net length ratio of 1:5. A small $4.6 \mathrm{~m}$ semirigid inflatable boat towed the net at a distance of $20 \mathrm{~m}$ from the boat, and a speed of approximately 1.5 knots. Bottom sampling was performed with a plankton net attached to an underwater scooter. This net was similar to the one used at the surface trawls, but the mouth diameter:net length ratio was 1:3 due to manoeuverability reasons. The bottom plankton trawls were undertaken at a distance of approximately $0.50 \mathrm{~m}$ from the rocky substrate. After reaching the bottom, the diver opened the net and begun the trawl following a direction parallel to the shoreline, contouring obstacles when needed. Five minutes later the diver would close the net and slowly ascend to the surface. Sampling speed was approximately 1.5 knots. All samples were performed over the whole extent of the rocky bottom, from 4 to $13 \mathrm{~m}$. In each bottom sample we followed the bottom contour at approximately the same depth. The average difference between maximum and minimum depths per bottom sample was $1.92 \mathrm{~m}(\mathrm{SD}=0.86)$. Hydrobios flowmeters were attached to both nets. Filtered volumes, sampling periods and number of larvae caught are shown in Table 1.

All samples were preserved in $4 \%$ saline formalin buffered with sodium borate for at least 1 month, before larvae were sorted and identified under a stereomicroscope to the lowest possible taxonomic level (species level when possible). We identified $94 \%$ of the larvae to family level (99\% in the bottom samples and $88 \%$ in the surface samples), $86 \%$ to genus level (97\% in the bottom samples and $71 \%$ in the surface samples) and $83 \%$ to species level $(95 \%$ in the bottom samples and $69 \%$ in the surface samples).
Table 1 Sampling periods, water volume filtered and number of larvae caught at the surface and bottom samples in each year

\begin{tabular}{|c|c|c|c|c|c|c|c|c|c|}
\hline \multirow[t]{2}{*}{ Depth } & \multirow[t]{2}{*}{ Year } & \multirow[t]{2}{*}{ Sampling period } & \multirow[t]{2}{*}{$N$} & \multicolumn{3}{|c|}{ Volume filtered $\left(\mathrm{m}^{3}\right)$} & \multicolumn{3}{|c|}{ Number of larvae } \\
\hline & & & & Mean & SD & Range & Mean & SD & Total \\
\hline \multirow[t]{3}{*}{ Surface } & 1999 & 26 May-30 Aug & 48 & 25.44 & 6.45 & $14.12-42.58$ & 22.29 & 24.17 & 1070 \\
\hline & 2000 & 31 May-21 Aug & 30 & 28.67 & 4.20 & $15.12-35.52$ & 12.87 & 9.63 & 386 \\
\hline & 2003 & 11 Jun-21 Aug & 27 & 28.93 & 6.09 & $16.31-42.75$ & 20.74 & 15.22 & 560 \\
\hline \multirow[t]{3}{*}{ Bottom } & 2001 & 26 Jun-09 Aug & 48 & 6.87 & 1.32 & $4.54-9.10$ & 20.19 & 29.23 & 969 \\
\hline & 2002 & 02 Jul-25 Jul & 54 & 7.22 & 2.15 & $3.07-11.34$ & 13.98 & 19.04 & 755 \\
\hline & 2003 & 19 May-07 Aug & 24 & 11.15 & 1.78 & $7.44-13.91$ & 35.38 & 31.58 & 849 \\
\hline
\end{tabular}


Photographs were taken to help in the identifications, using a digital camera attached to a stereomicroscope. Body length (BL), corresponding to notochord length in pre-flexion larvae or to standard length in post-flexion larvae, was measured to the nearest $0.01 \mathrm{~mm}$ using a micrometer scale. For larvae larger than $15.0 \mathrm{~mm}$ measurements were made using a caliper. A total of $14.5 \%$ of larvae in the surface samples and $5.1 \%$ in the bottom samples were in bad condition and were not measured.

\section{Data analysis}

\section{Composition and annual patterns of larval assemblages}

Larval abundances were calculated for every taxa identified in each sample and are expressed as the number of larvae $/ 1,000 \mathrm{~m}^{3}$. Two biodiversity indices were calculated for each sample, the Shannon diversity index $\left(H^{\prime}\right)$ using the natural logarithm in its formulation and the average taxonomic distinctness index (Delta*), which reflects the taxonomic spread of species among samples (Clarke and Warwick 2001). This index is based not just on the species abundances but also on the taxonomic distances between every pair of individuals; high Delta* values (maximum $=100$ ) reflect high taxonomic diversity in the assemblage (Clarke and Warwick 2001). Equal step-lengths were assumed between each taxonomic level. Four taxonomic levels were used, from species to order. Mean values and standard deviation of these indexes were calculated for each year at each depth strata.

Annual differences in total larval abundances and diversity indexes were tested with one-way ANOVA and Student-Newman-Keuls tests for post hoc comparisons, when homoscedascity assumptions were met after being tested with the Levene's test. If needed, variables were $\log (x+1)$ transformed. When variances were heterogeneous, a Kruskall-Wallis ANOVA was used and post hoc comparisons were performed with the Dunn's test. Using the same criteria, $T$-student tests or Mann-Whitney $U$ tests were used for the comparisons of overall abundance and diversity indexes between surface and bottom samples.

Owing to a possible effect of tide on larval distribution (Neilson and Perry 1990; Cowen 2002) and logistical constraints (it was not possible to standardize tide situation), tidal phase was randomized in this study. However, we tested for a possible interaction between tide and depth on larval abundance using a factorial ANOVA, with tidal phase and depth strata as factors. Since no interaction between these factors was found, but, when pooled together, homoscedascity assump- tions could not be met even after transformation (due to the great difference in variance between surface and bottom samples), we analysed these factors separately with one-way ANOVA and Student-Newman-Keuls tests for post hoc comparisons.

\section{Differences in larval assemblages between depth strata}

Using the relative abundance of each species, differences between the structure of surface and bottom assemblages were graphically displayed with a nonmetric multidimensional scaling (MDS) two-dimensional plot. The ordination was based on a triangular matrix of Bray-Curtis similarities after a $\log (x+1)$ data transformation. Samples in plots that are closer together are less distinct and a stress coefficient determines the relationship among samples from distinct groups (Clarke and Warwick 2001). Larvae which could not be identified were not considered in the analysis: $11.1 \%$ of the larvae present in surface samples (from which $87 \%$ were in the pre-flexion stage) and $0.58 \%$ of the larvae from the bottom samples $(98 \%$ of which were in the pre-flexion stage). Six groups were considered in the analysis, corresponding to the different years sampled at each depth.

In order to test for differences between groups a one-way analysis of similarities (ANOSIM) was performed. High $R$ values indicate differences between groups (Clarke and Warwick 2001). Similarity percentages analysis (SIMPER) was used to determine the species contribution to each group after $\log (x+1)$ transformation of the data, assuming a cut-off at $95 \%$. The MDS stress level was higher than 0.1 (Clarke and Warwick 2001), and therefore we performed a cluster analysis based on the Bray-Curtis similarities matrix with $\log (x+1)$ transformed data. To simplify the cluster graphical interpretation, we used the average similarity contribution of each species to the average similarity within each year at each depth, according to the SIMPER results. In order to understand the species composition at each depth, since low $R$ values were obtained in every pair-wise comparison between years in the same depth strata, inter-annual results were pooled together for the same depth before the SIMPER analysis.

\section{Ontogenetic vertical distribution patterns}

To access possible ontogenetic differences in the distribution of larvae between depth strata, the length of larvae of the most representative species was compared between the surface and bottom samples with $T$-student tests (the $\log x$ transformation was used 
when needed) or Mann-Whitney $U$ tests (if variances were heterogeneous even after transformation). Developmental stage of each larva was categorized into pre-flexion, incomplete flexion and post-flexion stages following Leis and Carson-Ewart (2000b). We considered all larval stages from hatching, including yolk-sac larvae.

The PRIMER 5 programme was used for the calculation of diversity indexes and multivariate analyses. STATISTICA 7 (StatSoft, Inc. 2004) was used for all other statistics.

\section{Results}

Composition and annual patterns of larval assemblages

A total of 4,589 larvae (2,016 from the surface samples and 2,573 from the bottom samples) were collected belonging to 62 identifiable taxa included in 22 families (Table 2). Most larvae caught belonged to species whose adults live in nearshore waters laying demersal eggs (e.g. Blenniidae, Gobiidae, Tripterygiidae, some Labridae). However, there were also a few coastal larvae hatching from pelagic eggs (e.g. Sparidae, Serranidae) and species whose adults live and spawn in coastal and shelf waters like Sardina pilchardus, Trachurus trachurus and Engraulis encrasicolus.

Although variation in total larval abundance among years was apparent for both depth strata (Fig. 2), total larval abundance was always higher at the bottom than at the surface and overall differences were significant $(Z=6.214, P<0.001)$. The inter-annual variation in larval density in the bottom samples was not significantly different $(H=4.26, d f=2, P=0.12)$, but at the surface significant variations between years were found $(F=3.673, d f=2, P<0.05)$, with larval densities observed in 2000 lower than both in 1999 $(P<0.05)$ and $2003(P<0.05)$. No differences of larval abundance were found among tidal phases at the surface $(F=0.46, d f=3, P=0.71)$, but significant results were obtained at the bottom $(F=4.81, d f=3$, $P<0.01)$ with more larvae occurring at low tide than at rising tide $(P<0.05)$.

Diversity was significantly higher in the surface samples (Table 3). Annual variation in diversity was significant at the bottom samples for both the Shannon diversity index and the average taxonomic distinctness index, with a decrease in the overall diversity in 2003 and an increase in taxonomic diversity in 2002. On the contrary, no significant changes in taxonomic diversity were found in the surface samples, but overall diversity exhibited a significant decrease in 2000 (Table 3).
Differences in larval assemblages between depth strata

The MDS graphical representation showed a clear distinction between the structure of surface and bottom assemblages (Fig. 3a), which was confirmed by the cluster analysis (Fig. 3b). ANOSIM revealed that these differences were significant (Global $R=0.46, P=0.001$; Table 4 ). There were low $R$ values in every pair-wise comparison between years in the same depth strata, but all comparisons between any surface layer group with any bottom layer group revealed high values of $R$ (above 0.50), showing significant differences between the structure of surface and bottom assemblages (Clarke and Warwick 2001).

The similarity percentages analysis (SIMPER) showed that surface assemblages included 16 taxa from which only six taxa explained $73.4 \%$ of the similarity among groups (Table 5). Larvae that contributed most to this similarity include sparids, serranids (Serranus sp.), blenniids (Parablennius pilicornis), clupeiformes (Sardina pilchardus), labrids (Coris julis) and tripterygiids (Tripterygion delaisi). In the bottom samples only six taxa were present, almost exclusively from coastal species which lay demersal eggs. The only exception was the sparid Boops boops which lays pelagic eggs but also breeds in nearshore waters. Gobiids dominated this assemblage with only two species, Pomatoschistus pictus and Gobius xanthocephalus, explaining together $73.79 \%$ of the similarity among groups (Table 5).

\section{Ontogenetic vertical distribution patterns}

Larvae present at the surface were significantly smaller than at the bottom (surface: mean $=2.99 \mathrm{~mm}, \mathrm{SD}=1.39$, range 1.07-17.07, $N=1,724$; bottom: mean $=7.24 \mathrm{~mm}$, $\mathrm{SD}=2.36$, range $1.10-23.00, N=2,442 ; \quad Z=48.62$, $P<0.001)$. This overall pattern was found for most species present at the bottom with the exceptions of Callionymus spp., Sparidae sp.1 and Tripterygion delaisi (Table 6). Most larvae caught at the surface were small and undeveloped $(83.0 \%$ of the larvae were less than $4 \mathrm{~mm} \mathrm{BL}$ and $92.3 \%$ were in the pre-flexion stage). On the contrary, larvae caught at the bottom were larger (94.8\% > 4 mm, see Fig. 4) and more developed (90.3\% were in the flexion or post-flexion stages).

During the analysis of the size distribution of the most representative species (according to the SIMPER analysis), an interesting pattern emerged for those species which were present at both depths. In most cases, only small larvae occurred at the surface whereas all size classes were present at the bottom (Fig. 5). For species which were abundant at the bottom, larvae 


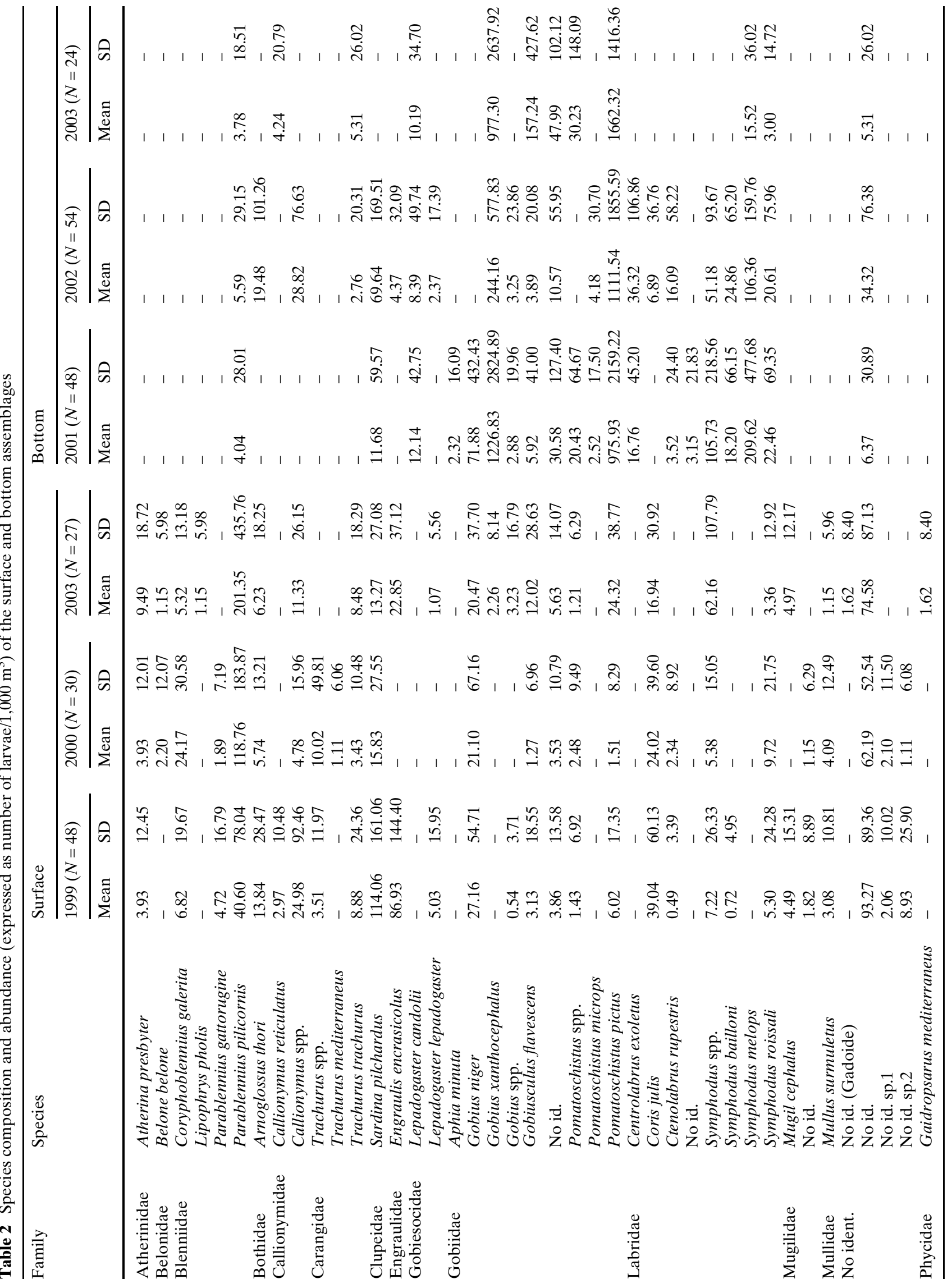




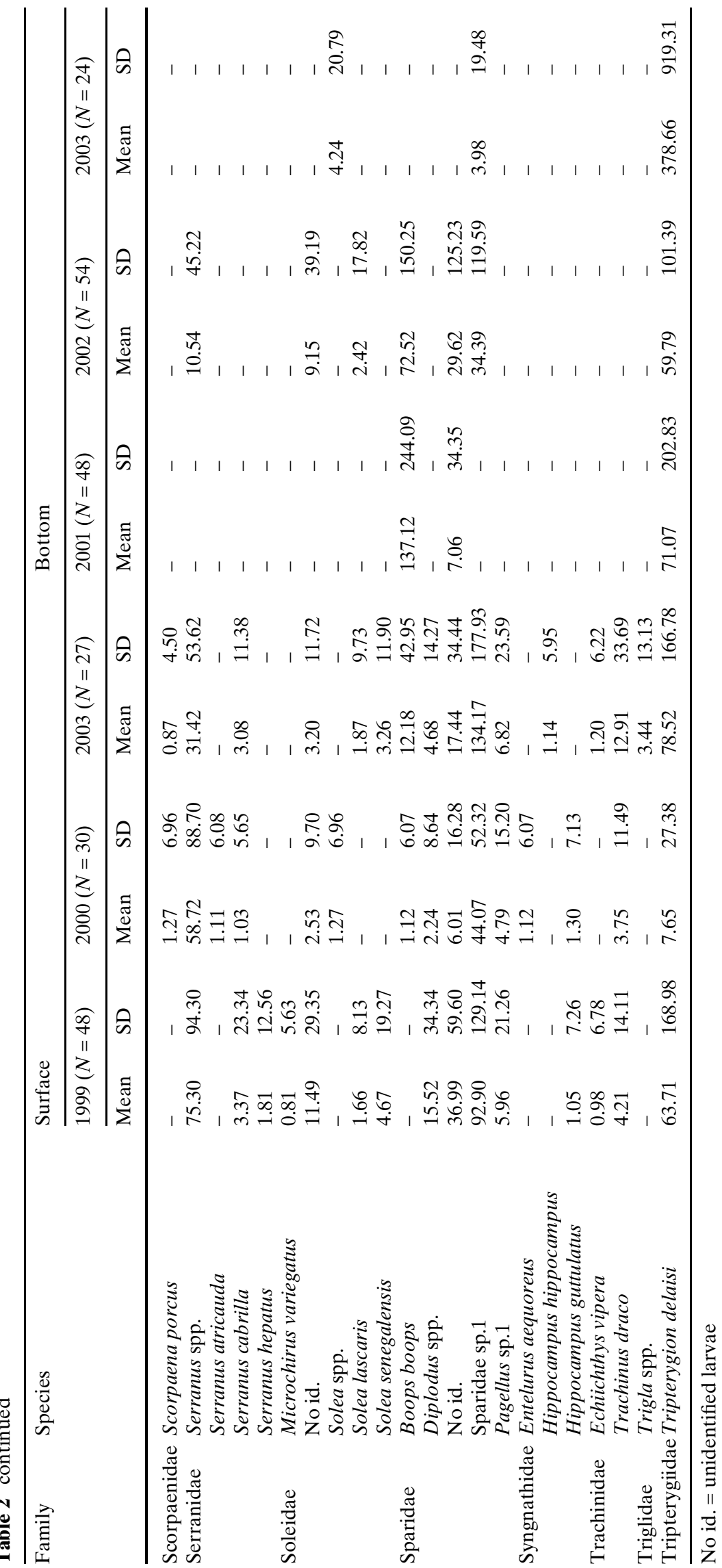




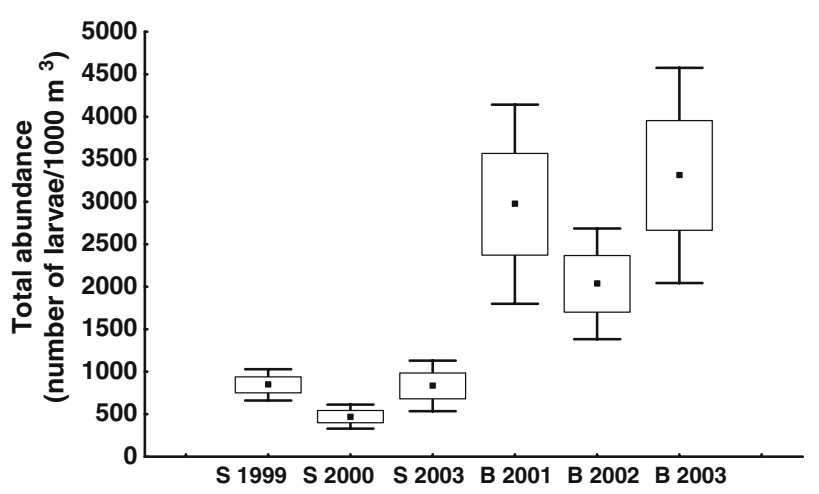

Fig. 2 Total larval abundance at each depth strata and in each year sampled. ( $S$ surface; $B$ bottom). Central square mean; large rectangle mean $\pm \mathrm{SE}$; whiskers mean $\pm 1.96 \mathrm{SE}$

from $4 \mathrm{~mm}$ to the $10-12 \mathrm{~mm}$ or to the $18-20 \mathrm{~mm}$ size classes (depending on the species considered) were present. These patterns of small larvae at the surface and different size classes at the bottom could be observed in the gobiids Pomatoschistus pictus, Gobiusculus flavescens and Gobius niger; the sparid Boops boops and in labrids from the genus Symphodus. Symphodus melops larvae constituted $55.6 \%$ of the Symphodus larvae present at the bottom where they were present in the different size classes. Small Symphodus larvae (2-4 mm size class) present at the surface and included in the category Symphodus spp., may belong to either S. melops or Symphodus cinereus, since adults of both species are common at the study site and both larvae have similar pigmentation patterns when newly hatched (Quignard 1967, 1968; Fives 1976). Finally, Tripterygion delaisi, the third most abundant species at the bottom, represents an exception to this pattern, with an overlap of size-class distribution for larvae caught at the surface and at the bottom with slightly bigger larvae present at the surface (Fig. 5).

\section{Discussion and conclusions}

The very nearshore larval fish assemblages studied in the present work were exclusively composed by shore or shelf-dwelling species. Larvae from shore fish species included sparids, serranids, blenniids, gobiids, tripterygiids and labrids, reflecting the adult fish assemblage occurring at the study area (Henriques et al. 1999). Larvae from shelf-dwelling spawners were mainly clupeids, carangids and engraulids.

These results generally agree with Sabatés et al. (2003) who found nearshore larval assemblages at a rocky shore in the northwest Mediterranean to be essentially composed by shorefish species (also including gobiids, sparids, labrids, tripterygiids and a few shelf species). Other studies found similar results in other geographic areas: New Zealand (Kingsford and Choat 1989); Gulf of California (Brogan 1994); South Africa (Tilney et al. 1996); Peru (Velez et al. 2005). Larvae from slope or oceanic families that are abundant off the Portuguese coast, like myctophids or paralepidids (John and Ré 1993), were not found.

Most coastal species known to breed at the Arrábida Marine Park during the spring and summer period (Henriques et al. 1999) were present in our samples. However, there were a few exceptions, like clingfishes (family Gobiesocidae). Some authors have shown that clingfish species can be abundant near reefs (e.g. Marliave 1986; Kingsford and Choat 1989; Tilney et al. 1996; Sabatés et al. 2003). Using light-traps we have been able to confirm this as we caught many clingfish larvae from all size classes in the study area (unpublished results). A possible explanation for the fact that, although clingfish larvae are present in the area they were not collected in our samples, could be related to the short planktonic larval duration (PLD) of these fishes (15 days for Apletodon dentatus and 13 days for Lepadogaster candolii; Raventós and

Table 3 Shannon diversity index $\left(H^{\prime}\right)$ and average taxonomic distinctness index $\left(\Delta^{*}\right)$ in each depth strata and year sampled

\begin{tabular}{|c|c|c|c|c|c|c|c|c|c|c|}
\hline Depth & Year & $N$ & Mean $H^{\prime}$ & $\mathrm{SD} H^{\prime}$ & Statistics & Post hoc test & $\operatorname{Mean} \Delta^{*}$ & $\mathrm{SD} \Delta^{*}$ & Statistics & Post hoc test \\
\hline \multirow[t]{3}{*}{ Surface } & 1999 & 47 & 1.65 & 0.53 & \multirow[t]{3}{*}{$F=4.44^{*}$} & 99-00*; & 83.06 & 18.61 & \multirow[t]{3}{*}{$F=1.72 n s$} & \multirow{8}{*}{$\begin{array}{l}01-02 * \\
02-03^{*}\end{array}$} \\
\hline & 2000 & 30 & 1.34 & 0.48 & & $00-03 *$ & 76.33 & 16.29 & & \\
\hline & 2003 & 26 & 1.65 & 0.35 & & & 80.96 & 4.68 & & \\
\hline \multirow[t]{3}{*}{ Bottom } & 2001 & 43 & 0.88 & 0.53 & \multirow[t]{3}{*}{$F=5.72 * *$} & $01-03 *$ & 53.24 & 25.86 & \multirow[t]{3}{*}{$F=5.38 * *$} & \\
\hline & 2002 & 53 & 1.03 & 0.46 & & $02-03 * *$ & 67.14 & 20.64 & & \\
\hline & 2003 & 24 & 0.62 & 0.46 & & & 53.27 & 22.64 & & \\
\hline \multirow[t]{2}{*}{ Surface $\times$ bottom } & & 103 & 1.56 & 0.50 & \multirow[t]{2}{*}{$t=-9.81 * * *$} & & 80.57 & 15.66 & \multirow[t]{2}{*}{$Z=-9.44 * * *$} & \\
\hline & & 120 & 0.90 & 0.51 & & & 59.39 & 23.86 & & \\
\hline
\end{tabular}

$F=$ value of one-way ANOVA (Newman-Keuls post hoc test); $t=$ value of $t$ test for independent samples; $Z=$ value of Mann-Whitney $U$ test; $n s$ not significant

$* P<0.05 ; * * P<0.01 ; * * * P<0.001$ 


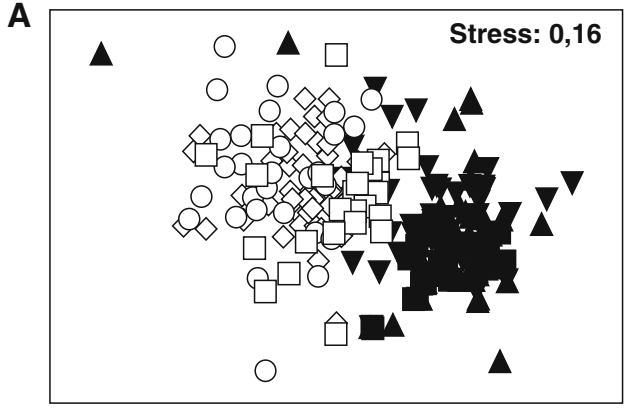

A B 2001

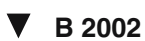

B 2003

S 1999

S 2000

S 2003

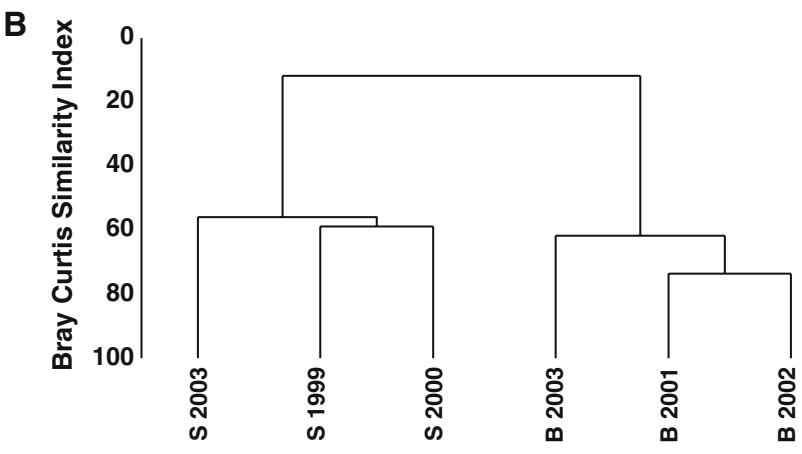

Fig. 3 a Non-metric multidimensional scaling (MDS) plot showing samples for each year and depth strata ( $B$ bottom samples; $S$ surface samples). The spatial segregation of surface and bottom samples reflects differences in the structure of the assemblages. b Cluster analysis on $\log (x+1)$ transformed data based on a BrayCurtis similarity matrix for the different years and depth strata $(B$ bottom samples; $S$ surface samples)

Macpherson 2001). The fast development of ontogenetic structures, which could contribute to an active behaviour of net avoidance, is probably associated with these short PLDs. In fact, these species hatch at a large size with an advanced stage of development and are probably able to actively swim and find shelter (e.g. hiding among algal tufts, Gonçalves et al. 2003), thus being able to avoid the net very early in life. This could explain why they were caught using light-traps, but absent from the bottom and surface sampling using nets.

Larval assemblages at the surface and at the bottom were clearly distinct, indicating that this very nearshore larval fish assemblage is vertically structured at a small scale (a few metres). The surface assemblage was much more diverse, being composed by coastal larvae hatching from both pelagic and demersal eggs. Although filtered volumes were also higher at the surface (due to the different net diameter: net length ratios of the nets), similarity was higher among bottom samples. This fact, together with the larger size of larvae collected in the bottom samples (larger larvae could be expected to more easily avoid the net actively than smaller larvae), seems to indicate that the detected
Table 4 Summary of one-way analysis of similarity (ANOSIM) with pair-wise comparisons of larval assemblages between years and depth strata

\begin{tabular}{llll}
\hline & & $R$ & Significance \\
\hline \multirow{3}{*}{ Surface } & Global $R$ & 0.46 & 0.001 \\
& S 1999 vs S 2000 & 0.24 & 0.001 \\
Bottom & S 1999 vs S 2003 & 0.18 & 0.001 \\
S 2000 vs S 2003 & 0.16 & 0.001 \\
Surface $\times$ bottom & B 2001 vs B 2002 & 0.04 & 0.02 \\
& B 2001 vs B 2003 & 0.09 & 0.04 \\
& B 2002 vs B 2003 & 0.03 & 0.23 \\
& S 1999 vs B 2001 & $\mathbf{0 . 7 5}$ & 0.001 \\
S 1999 vs B 2002 & $\mathbf{0 . 6 8}$ & 0.001 \\
& S 1999 vs B 2003 & $\mathbf{0 . 8 1}$ & 0.001 \\
& S 2000 vs B 2001 & $\mathbf{0 . 6 9}$ & 0.001 \\
S 2000 vs B 2002 & $\mathbf{0 . 7 1}$ & 0.001 \\
& S 2000 vs B 2003 & $\mathbf{0 . 7 8}$ & 0.001 \\
S 2003 vs B 2001 & $\mathbf{0 . 5 5}$ & 0.001 \\
S 2003 vs B 2002 & $\mathbf{0 . 5 5}$ & 0.001 \\
S 2003 vs B 2003 & $\mathbf{0 . 6 5}$ & 0.001 \\
\hline
\end{tabular}

Nine hundred and ninety-nine permutations were used for each test. The value of the $R$ statistic and its significance are shown. Numbers in bold represent $R$ values higher than 0.5

$S$ surface, $B$ bottom

differences in diversity were not due to the different filtered volumes between surface and bottom samples. The bottom assemblage was composed by a small number of exclusively nearshore reef-associated species laying demersal eggs (like gobiids, tripterygiids and labrids of the genus Symphodus). The exception was the sparid Boops boops, which is abundant in the study area and also breeds nearshore (Henriques et al. 1999), but spawns pelagic eggs.

At the surface, inter-annual fluctuations were detected, with the year 2000 presenting significant lower larval densities and diversities. These variations could be related to the inter-annual fluctuations of the North Atlantic Oscillation (NAO), since, coincidently, the year 2000 presented particularly high winter NAO Index values. ${ }^{1}$ However, the pattern of variation was different at the bottom. Therefore, more data are needed to further analyse this relation, although it is possible that inter-annual differences could be caused by more general climatic fluctuations. This relation has been recently described for this study area concerning the adult rocky fish assemblage (Henriques et al. 2006). Despite these inter-annual fluctuations, overall larval density was always much higher at the bottom than at the surface.

\footnotetext{
${ }^{1}$ See NAO Index data provided by the Climate Analysis Section, NCAR, Boulder, USA, Hurrell (1995) at http://www.cgd. ucar.edu/cas/jhurrell.
} 
Fig. 4 Overall size class distribution of larvae caught at the surface and bottom samples. $B L$ body length
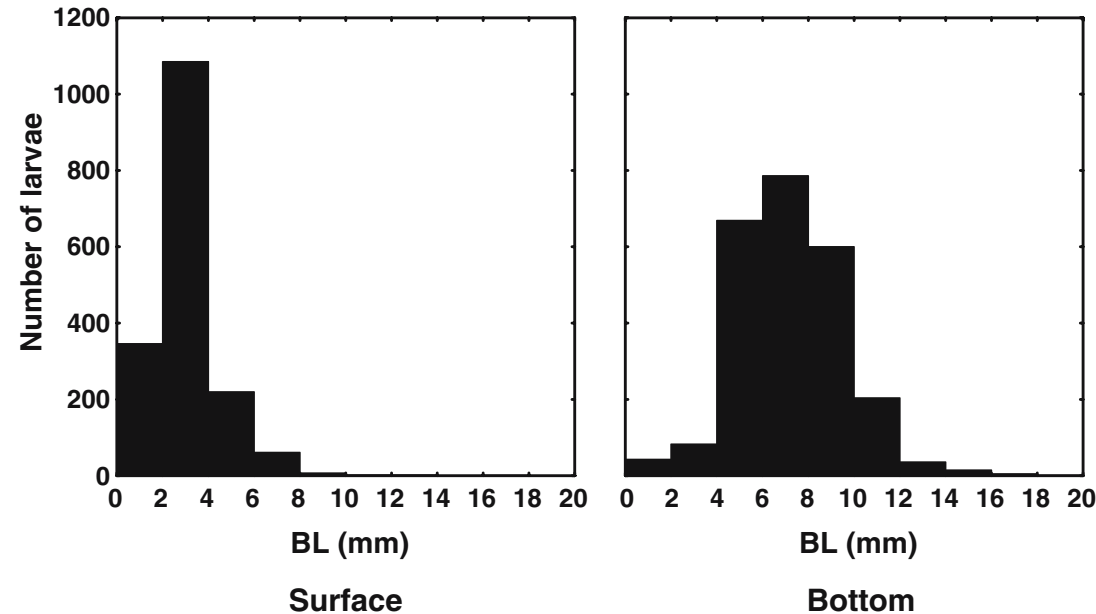

Table 5 Similarity percentages analysis (SIMPER) results for the surface and bottom assemblages with inter-annual results pooled together for the same depth

\begin{tabular}{|c|c|c|c|}
\hline Taxa & $\begin{array}{l}\text { Average } \\
\text { similarity }\end{array}$ & $\begin{array}{l}\text { Contribution } \\
(\%)\end{array}$ & $\begin{array}{l}\text { Cumulative } \\
(\%)\end{array}$ \\
\hline Surface & 25.73 & & \\
\hline Sparidae sp.1 & 4.88 & 18.96 & 18.96 \\
\hline Serranus spp. & 4.18 & 16.23 & 35.19 \\
\hline Parablennius pilicornis & 3.39 & 13.18 & 48.37 \\
\hline Sardina pilchardus & 3.20 & 12.44 & 60.80 \\
\hline Coris julis & 1.80 & 7.00 & 67.80 \\
\hline Tripterygion delaisi & 1.44 & 5.60 & 73.40 \\
\hline Engraulis encrasicolus & 1.22 & 4.76 & 78.16 \\
\hline Sparidae spp. & 0.93 & 3.63 & 81.79 \\
\hline Coryphoblennius galerita & 0.85 & 3.30 & 85.09 \\
\hline Gobius niger & 0.83 & 3.22 & 88.31 \\
\hline Symphodus spp. & 0.48 & 1.87 & 90.18 \\
\hline Arnoglossus thori & 0.34 & 1.31 & 91.49 \\
\hline Trachurus trachurus & 0.28 & 1.08 & 92.57 \\
\hline Pomatoschistus pictus & 0.25 & 0.98 & 93.54 \\
\hline Diplodus spp. & 0.22 & 0.84 & 94.39 \\
\hline Callionymus spp. & 0.21 & 0.83 & 95.22 \\
\hline Bottom & 33.99 & & \\
\hline Pomatoschistus pictus & 19.27 & 56.68 & 56.68 \\
\hline Gobius xanthocephalus & 5.82 & 17.11 & 73.79 \\
\hline Tripterygion delaisi & 2.48 & 7.29 & 81.08 \\
\hline Symphodus melops & 2.24 & 6.59 & 87.67 \\
\hline Boops boops & 1.58 & 4.64 & 92.31 \\
\hline Symphodus spp. & 1.17 & 3.44 & 95.75 \\
\hline
\end{tabular}

Average similarity values and percentage contribution of the most representative species to the average similarity within each group, after $\log (x+1)$ transformation of abundance data, are shown. Cut-off for low contributions $=95 \%$

Although tidal effects were not specifically addressed in this study and tidal phase was randomized in our sampling design, a preliminary analysis showed that samples collected in the bottom at low tide contained significantly higher larval abundances than at the rising tide. In future work, this possible tidal effect should be explored in order to evaluate if these patterns are consistent and determine if they are a simple concentration effect of larvae in a small water column at low tide and/or if they reflect any behavioural mechanism which allows these larvae to be retained nearshore. The fact that surface and bottom patterns were strikingly different indicates that larvae must have an active role in the observed patterns.

One could argue that the described vertical patterns occurred during the day and that they could be different at night, since it is well established that nocturnal ascent of larger larvae is one of the commonest patterns of diel vertical migration of coastal larval fish (Leis 1991a; Fisher 2004). However, night trawling at the surface in the same period of the year showed that, for the species considered, the patterns found during the day are maintained at night, with only small larvae found in sub-surface trawls (unpublished results).

The high diversity values found at the surface and the high density values found at the bottom indicate that, for a selected number of species, larvae school near the substrate at high densities. The gobies Pomatoschistus pictus and Gobius xanthocephalus dominated this assemblage. Several studies have documented the presence of Gobiidae larvae nearshore (Leis 1986a, 1993; Smith et al. 1987; Kingsford and Choat 1989; Kobayashi 1989; Gray 1993; Brogan 1994; Gray and Miskiewicz 2000; Kingsford 2001; Sabatés et al. 2003; Sponaugle et al. 2003), but little is known about the small-scale distribution patterns near the substrate in very nearshore waters. Moreover, some gobies are present nearshore at all size classes of their planktonic life in different environments. Leis et al. (1998) found this pattern in gobies occurring in shallow waters at Taiaro atoll and concluded that they completed their entire planktonic life cycle near the reefs. The same result was obtained by Leis et al. (2003) for 
Table 6 Body lengths (in $\mathrm{mm}$ ) for larvae of the most abundant species present in the surface and bottom samples

Statistical tests were computed for species with at least five individuals at both depth strata

$t=t$ test for independent samples; $Z$ = Mann-Whitney $U$ test; $n s$ not significant; No id. = unidentified larvae

$* P<0.05, * * P<0.01$ $* * * P<0.001$

\begin{tabular}{|c|c|c|c|c|c|c|c|c|}
\hline \multirow[t]{2}{*}{ Family } & \multirow[t]{2}{*}{ Species } & \multicolumn{3}{|c|}{ Surface } & \multicolumn{3}{|c|}{ Bottom } & \multirow[t]{2}{*}{ Statistics } \\
\hline & & Mean & SD & $N$ & Mean & SD & $N$ & \\
\hline Atherinidae & Atherina presbyter & 6.26 & 0.44 & 14 & - & - & - & \\
\hline \multirow[t]{2}{*}{ Blenniidae } & Coryphoblennius galerita & 3.23 & 0.22 & 27 & - & - & - & \\
\hline & Parablennius pilicornis & 2.66 & 0.16 & 229 & 2.45 & 0.18 & 3 & \\
\hline Bothidae & Arnoglossus thori & 2.35 & 0.34 & 21 & 2.82 & 0.33 & 5 & $t=2.78 *$ \\
\hline Callionymidae & Callionymus spp. & 1.70 & 0.20 & 34 & 1.54 & 0.15 & 9 & $t=2.27 *$ \\
\hline \multirow[t]{2}{*}{ Carangidae } & Trachurus spp. & 1.81 & 0.60 & 11 & - & - & - & \\
\hline & Trachurus trachurus & 3.31 & 0.97 & 19 & 2.30 & 0.06 & 2 & \\
\hline Clupeidae & Sardina pilchardus & 4.56 & 1.21 & 156 & 4.68 & 1.62 & 22 & $t=-0.44 n s$ \\
\hline Engraulidae & Engraulis encrasicolus & 3.53 & 0.64 & 103 & 3.20 & - & 1 & \\
\hline Gobiesocidae & Lepadogaster candolii & - & - & - & 4.71 & 0.60 & 10 & \\
\hline \multirow[t]{5}{*}{ Gobiidae } & Gobius niger & 2.83 & 0.56 & 60 & 5.23 & 1.54 & 27 & $Z=6.49 * * *$ \\
\hline & Gobius xanthocephalus & 5.55 & 3.75 & 2 & 6.38 & 1.50 & 674 & \\
\hline & Gobiusculus flavescens & 2.73 & 1.07 & 12 & 6.37 & 1.28 & 37 & $t=8.87 * * *$ \\
\hline & Pomatoschistus spp. & 2.96 & 0.88 & 4 & 6.77 & 1.51 & 14 & \\
\hline & Pomatoschistus pictus & 2.47 & 0.61 & 23 & 8.44 & 2.10 & 1191 & $t=21.67 * * *$ \\
\hline \multirow[t]{7}{*}{ Labridae } & Centrolabrus exoletus & - & - & - & 7.39 & 1.19 & 19 & \\
\hline & Coris julis & 2.28 & 0.50 & 61 & 2.16 & 0.34 & 2 & \\
\hline & Ctenolabrus rupestris & 2.55 & 0.23 & 3 & 8.48 & 5.56 & 7 & \\
\hline & Symphodus spp. & 2.83 & 0.17 & 63 & 6.97 & 2.39 & 53 & $Z=8.90^{* * *}$ \\
\hline & Symphodus bailloni & - & - & - & 5.36 & 0.82 & 14 & \\
\hline & Symphodus melops & - & - & - & 6.47 & 1.18 & 104 & \\
\hline & Symphodus roissali & 2.86 & 0.19 & 13 & 5.42 & 1.77 & 14 & $Z=3.62 * * *$ \\
\hline Serranidae & Serranus spp. & 2.15 & 0.39 & 135 & 1.97 & 0.32 & 3 & \\
\hline Soleidae & No id. & 2.13 & 0.35 & 12 & 1.47 & 0.13 & 3 & \\
\hline \multirow[t]{5}{*}{ Sparidae } & Boops boops & 5.91 & 1.17 & 9 & 9.05 & 2.13 & 62 & $t=4.31 * * *$ \\
\hline & Diplodus spp. & 2.90 & 0.30 & 20 & - & - & - & \\
\hline & No id. & 2.47 & 0.46 & 59 & 2.74 & 1.42 & 11 & $t=0.54 \mathrm{~ns}$ \\
\hline & Sparidae sp.1 & 2.31 & 0.68 & 222 & 1.79 & 0.35 & 12 & $Z=2.34^{*}$ \\
\hline & Pagellus sp.1 & 2.95 & 0.30 & 14 & - & - & - & \\
\hline Trachinidae & Trachinus draco & 2.52 & 0.34 & 16 & - & - & - & \\
\hline Tripterygiidae & Tripterygion delaisi & 5.39 & 1.15 & 127 & 4.67 & 0.62 & 119 & $Z=5.06^{* * *}$ \\
\hline
\end{tabular}

several fish families (including the Gobiidae) in four lagoons at two atolls and one island in the French Polynesia. In temperate waters, Beyst et al. (1999) sampled the hyperbenthos at a maximum depth of $10 \mathrm{~m}$, in subtidal and tidal marshes at the Dutch Delta, and found Pomatoschistus microps and Pomatoschistus lozanoi larvae within the full range of developmental sizes (3$20 \mathrm{~mm}$ ). Drake and Arias (1991) sampled larvae in a shallow coastal inlet at south-west Spain and described that $P$. microps was the most abundant species with larvae ranging from 5 to $13 \mathrm{~mm}$ while Gobius paganellus ranged from 7 to $13 \mathrm{~mm}$. Brogan (1994) also found larvae of reef-associated species to be present in all size classes near reefs at the Gulf of California.

The larvae from the surface assemblage were mostly small and undeveloped. This indicates that these larvae are essentially newly hatched, which is in accordance with the presence of spawning grounds for most of these species in the study area. The absence of bigger larvae could be indicative of net avoidance by more developed larvae at the surface, given the small size of the net. However, more developed larvae were caught near the bottom with a similar net. On the other hand, the light intensity is not much attenuated near the shallow bottom and therefore the ability of larvae to visually avoid the net is probably similar at both depths. Furthermore, samples collected at night also contained mostly less developed larvae (own unpublished results).

For some of the most abundant species occurring at the bottom, our results provide evidence of depthrelated ontogenetic distribution patterns, with smaller larvae, mostly newly hatched, at the surface and larger and more developed larvae at the bottom. This is true for Pomatoschistus pictus, Gobiusculus flavescens, Gobius niger, Boops boops and probably for Symphodus melops. Moreover, larvae of these species were found at the bottom in the whole size range of their planktonic phase. Size at settlement varies with the species considered: around $17-18 \mathrm{~mm}$ for $P$. pictus; $12 \mathrm{~mm}$ for G. flavescens; and $9 \mathrm{~mm}$ for G. niger (Petersen 1919; Russell 1976). In Gobius xanthocephalus, size at settlement is unknown, but larvae were present in the bottom samples at up to the $14-16 \mathrm{~mm}$ size class. This indicates that this species is, most likely, also completing its planktonic life nearshore. In the case of 
Fig. 5 Size class distribution at the surface and bottom samples for species that occur with $>25$ individuals at the bottom samples. Dashed line surface samples; solid line bottom samples. $B L$ Body length
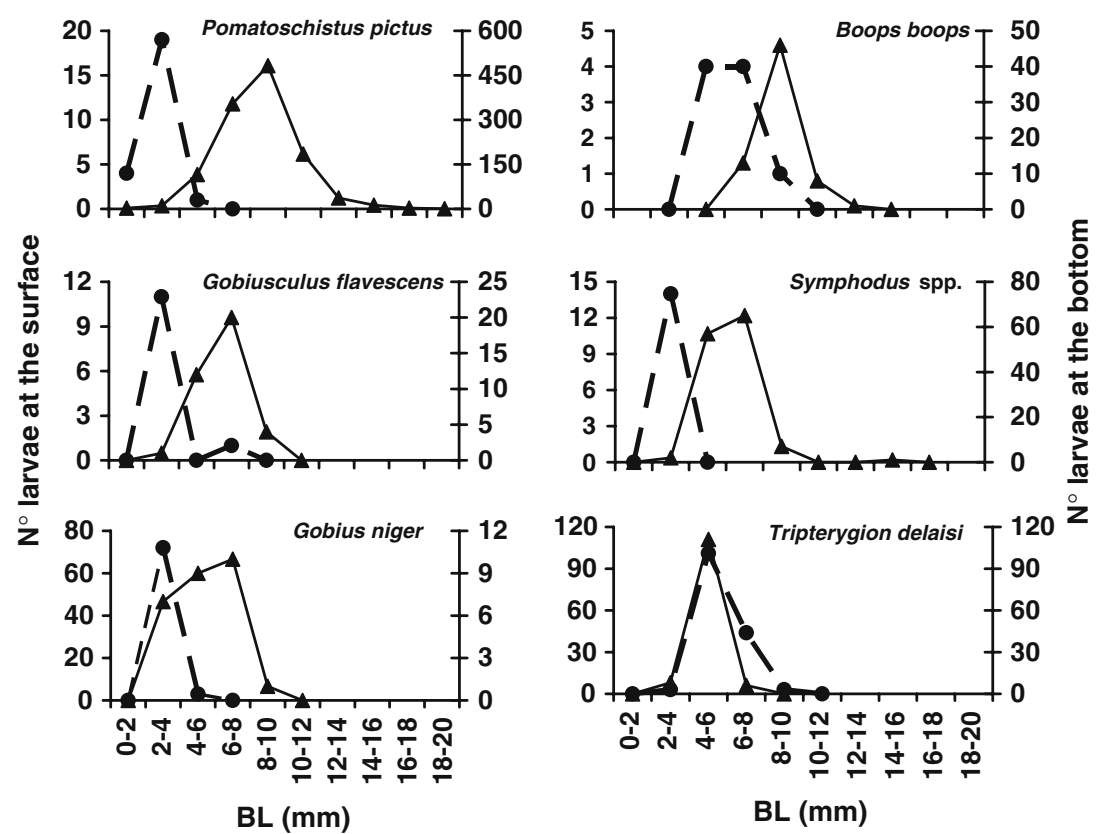

B. boops, larvae settle within 16-18 days at a TL of $12 \mathrm{~mm}$ (Raventós and Macpherson 2001).

The vertical distribution of fish larvae may influence larval dispersal (Sponaugle et al. 2002; Paris and Cowen 2004; Leis 2006); in particular, remaining near the bottom where flow is reduced may favour larval retention near reefs (Leis 1986b; Steffe 1990; Breitburg 1989, 1991; Breitburg et al. 1995). Retention of larvae near reefs has been documented in recent years in different systems and is presently identified as an important mechanism of self-recruitment for some coral reef populations (e.g. Jones et al. 1999, 2005; Swearer et al. 1999, 2002; Sponaugle et al. 2002; Taylor and Hellberg 2003; Paris and Cowen 2004). One of the advantages of nearshore retention for coastal species is the ability to find a suitable habitat to settle. Dispersion may increase mortality since oceanographic processes influencing larval transport are variable, both temporally and spatially, and if larvae are not transported to an adequate habitat, they can be lost (Hickford and Schiel 2003). Although the length of larval life has been proposed as one of the primary determinants of dispersal ability (Thresher et al. 1989; Sponaugle et al. 2002; Lester and Ruttenberg 2005), this relationship is not universal (see Lester and Ruttenberg 2005). Nonetheless, larvae with a small PLD would have more difficulty in returning to coastal habitats after pelagic dispersal in the ocean and in choosing the right habitat to settle. The data available on PLDs for some of the main species found at our study site show that, for Boops boops and Symphodus melops, PLD is less than 19 days (Raventós and Macpherson 2001). For Pomatoschistus pictus and Gobius xanthocephalus,
PLDs are not known, but for other gobies which occur at our study area somewhat longer times have been described (25 and 22 days for Gobius paganellus and Gobius cobitis, respectively; Gil et al. 1997; Borges et al. 2003).

When compared with larvae hatching from pelagic eggs, shorefish larvae hatching from demersal eggs are larger and typically have functional eyes, developed fins and guts, and better swimming abilities (Thresher 1984; Hickford and Schiel 2003). Therefore, retention is more likely to occur in these kinds of larvae (Sponaugle et al. 2002). However, larvae from some of these species seem to disperse. For instance, for the most abundant blenny at our site, Parablennius pilicornis, small larvae were very abundant in surface samples but almost no larvae were caught at the bottom. Drake and Arias (1991) also found only small Parablennius sp. larvae $(3-5 \mathrm{~mm})$ inshore. Some authors have suggested that blenniids disperse away from reefs (Brogan 1994). The long PLD (over 70 days at controlled conditions, personal communication by C. Faria) and welldeveloped pectoral fins of $P$. pilicornis larvae make them good candidates for dispersal. Larvae of this species are often found offshore in the upper layers of the water column (Olivar 1990).

Our results seem to indicate that, although PLD, size and development characteristics at hatching can be important in determining the larval capability to remain near the adults' habitat in these coastal species, other factors must be involved. Larval swimming and sensory abilities and orientation capabilities may also have a strong impact in dispersal patterns as larvae can actively influence their position in the water column 
(Leis and Carson-Ewart 1999, 2000a; Victor and Wellington 2000; Montgomery et al 2001; Cowen 2002; Fisher and Bellwood 2002b; Leis 2002, 2006; Leis and McCormick 2002; Mora and Sale 2002; Myrberg and Fuiman 2002; Fisher and Wilson 2004; Fisher 2005).

The data presented herein indicate that, for some of the most abundant coastal fish species that occurred at our study site, larvae can complete their entire planktonic phase in the vicinity of the adults' habitats. Moreover, they seem to be able to actively choose bottom habitats very early in their pelagic phase and not just in the pre-settlement stage, as is most commonly reported (Leis 2006). For many of these species, larvae are probably able to remain near the bottom, as soon as their swimming and sensory abilities develop. The observed vertical distribution patterns, combined with other factors, could influence horizontal positioning, promoting retention near the benthic rocky habitats at the study area. Larval distribution patterns depend on the interaction between physical oceanographic features and biological factors, like the adults' behaviour and ecology, life history traits, PLD, larval behaviour and sensory capabilities (Cowen 2002; Leis 2002, 2006; Sponaugle et al. 2002), and are most likely species-specific. The extent to which the results presented in this paper could influence self-recruitment in these assemblages needs further investigation. For instance, the relationship often found in temperate waters between larval dispersal patterns and mode of spawning can in fact be stronger in sheltered coasts (Hickford and Schiel 2003). Although this relationship was not found in our study, the degree of larval retention near reefs can be favoured by the sheltered conditions of the Arrábida Marine Park shore. It is therefore possible that the vertical distribution patterns found in this study differ, for some species, from those found in more exposed shores (Leis 2006). Studies focusing on the active behaviour of larvae and their sensory and swimming abilities as well as comparisons of larval distributions for the same species in more exposed shores may further contribute to understand the very nearshore distribution patterns described in this paper.

Acknowledgments This study was supported by the Portuguese Science and Technology Foundation [Fundação para a Ciência e a Tecnologia (FCT)] as part of the project POCTI/BSE/38350/ 2001 and through the Pluriannual Program (R\&D Unit 331/94). FCT also supported the PhD grants of R. Borges (SFRH/BD/ 4852/2001) and R. Beldade (SFRH/BD/1013/2000). We would like to thank A. Chícharo, R. Ben-Hamadou and J. Maroco for their help with the statistical analysis, M. Barbosa, A. Catarino, J. Martins, N. Souza and S. Vizinho for assistance in the field and lab work and the Oceanographic Museum of Parque Natural da Arrábida for all the support. Sampling and laboratory procedures comply with current Portuguese legislation.

\section{References}

Beyst B, Mees J, Cattrijsse A (1999) Early postlarval fish in the hyperbenthos of the Dutch Delta (south-west Netherlands). J Mar Biol Assoc UK. DOI 10.1017/S0025315498000861

Boehlert GW, Mundy BC (1993) Ichthyoplankton assemblages at seamounts and oceanic islands. Bull Mar Sci 53:336-361

Boehlert GW, Gadomski DM, Mundy BC (1985) Vertical distribution of ichthyoplankton off the Oregon coast in spring and summer months. Fish Bull US 83:611-621

Borges R, Faria C, Gil F, Gonçalves EJ, Almada VC (2003) Embryonic and larval development of Gobius paganellus (Pisces: Gobiidae). J Mar Biol Assoc UK. DOI 10.1017/ S0025315403008415h

Breitburg DL (1989) Demersal schooling prior to settlement by larvae of the naked goby. Environ Biol Fish. DOI 10.1007/ BF00001026

Breitburg DL (1991) Settlement patterns and presettlement behavior of the naked goby, Gobiosoma bosci, a temperate oyster reef fish. Mar Biol. DOI 10.1007/BF01319389

Breitburg DL, Palmer MA, Loher T (1995) Larval distributions and the spatial patterns of settlement of an oyster reef fish: responses to flow and structure. Mar Ecol Prog Ser 125:45-60

Brewer GD, Kleppel GS (1986) Diel vertical distribution of fish larvae and their prey in nearshore waters of southern California. Mar Ecol Prog Ser 27:217-226

Brogan MW (1994) Distribution and retention of larval fishes near reefs in the Gulf of California. Mar Ecol Prog Ser 115:113

Clarke KR, Warwick RM (2001) Change in marine communities: an approach to statistical analysis and interpretation, 2nd edn. PRIMER-E Ltd, Plymouth

Conway DVP, Coombs SH, Smith C (1997) Vertical distribution of fish eggs and larvae in the Irish Sea and southern North Sea. ICES J Mar Sci. DOI 10.1006/jmsc.1996.0176

Cowen RK (2002) Larval dispersal and retention and consequences for population connectivity. In: Sale PF (ed) Coral reef fishes: dynamics and diversity in a complex ecosystem. Academic, San Diego, pp 149-170

Cowen RK, Hare JA, Fahay MP (1993) Beyond hydrography: can physical processes explain larval fish assemblages within the Middle Atlantic Bight? Bull Mar Sci 53:567-587

Doherty PJ, Carleton JH (1997) The distribution and abundance of pelagic juvenile fish near Grub Reef, Central Great Barrier Reef. Proc 8th Int Coral Reef Sym Panama 2:11551160

Drake P, Arias AM (1991) Ichthyoplankton of a shallow coastal inlet in south-west Spain: factors contributing to colonization and retention. Estuar Coast Shelf Sci. DOI 10.1016/02727714(91)90048-G

Fisher R (2004) Nocturnal vertical distribution of late-stage larval coral reef fishes off the leeward side of Lizard Island, Great Barrier Reef, Australia. Bull Mar Sci 75:439-451

Fisher R (2005) Swimming speeds of larval coral reef fishes: impacts on self-recruitment and dispersal. Mar Ecol Prog Ser 285:223-232

Fisher R, Bellwood DR (2002a) A light trap design for stratumspecific sampling of reef fish larvae. J Exp Mar Biol Ecol. DOI 10.1016/s0022-0981(01)00384-7

Fisher R, Bellwood DR (2002b) The influence of swimming speed on sustained swimming performance of late-stage reef fish larvae. Mar Biol. DOI 10.1007/S00227-001-0758-5

Fisher R, Wilson SK (2004) Maximum sustainable swimming speeds of late-stage larvae of nine species of reef fishes. J Exp Mar Biol Ecol. DOI 10.1016/j.jembe.2004.06.009 
Fives JM (1976) Labridae of the eastern north Atlantic. Fiches D'Identification du Zooplancton. Cons Int Exp Mer 149:1-7

Gil MF, Gonçalves EJ, Faria C, Almada VC, Baptista C, Carreiro $\mathrm{H}$ (1997) Embryonic and larval development of the giant goby Gobius cobitis (Pisces: Gobiidae). J Nat Hist 31:799_ 804

Gonçalves EJ, Henriques M, Almada VC (2003) Use of a temperate reef-fish community to identify priorities in the establishment of a marine protected area. In: Beumer JP, Grant A, Smith DC (eds) Aquatic protected areas: what works best and how do we know? Proceedings of the world congress of aquatic protected areas, Cairns, pp 261-272

Gray CA (1993) Horizontal and vertical trends in the distributions of larval fishes in coastal waters off central New South Wales, Australia. Mar Biol. DOI 10.1007/BF00355483

Gray CA (1998) Diel changes in vertical distributions of larval fishes in unstratified coastal waters off southeastern Australia. J Plankton Res 20:1539-1552

Gray CA, Miskiewicz AG (2000) Larval fish assemblages in southeast Australian coastal waters: seasonal and spatial structure. Estuar Coast Shelf Sci. DOI 10.1006/ecss.1999.0595

Hendriks IE, Wilson DT, Meekan MG (2001) Vertical distributions of late stage larval fishes in the nearshore waters of the San Blas Archipelago, Caribbean Panama. Coral Reefs. DOI $10.1007 /$ S003380100139

Henriques M, Gonçalves EJ, Almada VC (1999) The conservation of littoral fish communities: a case study at Arrábida coast (Portugal). In: Almada VC, Oliveira RF, Gonçalves EJ (eds) Behaviour and conservation of littoral fishes. ISPA, Lisboa, pp 473-519

Henriques M, Gonçalves EJ, Almada VC (2006) Rapid shifts in a marine fish assemblage follow fluctuations in winter sea conditions. Mar Ecol Prog Ser (in press)

Hickford MJH, Schiel DR (2003) Comparative dispersal of larvae from demersal versus pelagic spawning fishes. Mar Ecol Prog Ser 252:255-271

Jenkins GP, Welsford DC, Keough MJ, Hamer PA (1998) Diurnal and tidal vertical migration of pre-settlement King George whiting Sillaginodes punctata in relation to feeding and vertical distribution of prey in a temperate bay. Mar Ecol Prog Ser 170:239-248

Jenkins GP, Black KP, Keough MJ (1999) The role of passive transport and the influence of vertical migration on the presettlement distribution of a temperate, demersal fish: numerical model predictions compared with field sampling. Mar Ecol Prog Ser 184:259-271

John H-Ch, Ré P (1993) Cross-shelf zonation, vertical distribution, and drift of fish larvae off northern Portugal during weak upwelling. Copenhagen Denmark Ices L 33:1-18

Jones GP, Milicich MJ, Emslie MJ, Lunow C (1999) Self-recruitment in a coral reef fish population. Nature. DOI 10.1038/ 45538

Jones GP, Planes S, Thorrold SR (2005) Coral reef fish larvae settle close to home. Curr Biol. DOI 10.1016/j.cub.2005.06.061

Kendall AW Jr, Naplin NA (1981) Diel-depth distribution of summer ichthyoplankton in the Middle Atlantic Bight. Fish Bull US 79:705-726

Kingsford MJ (2001) Diel patterns of abundance of presettlement reef fishes and pelagic larvae on a coral reef. Mar Biol. DOI $10.1007 / \mathrm{s} 002270000455$

Kingsford MJ, Choat JH (1989) Horizontal distribution patterns of presettlement reef fish: are they influenced by the proximity of reefs? Mar Biol. DOI 10.1007/BF00428124

Kingsford MJ, Finn M (1997) The influence of phase of the moon and physical processes on the input of presettlement fishes to coral reefs. J Fish Biol 51(Suppl A):176-205
Kobayashi DR (1989) Fine-scale distribution of larval fishes: patterns and processes adjacent to coral reefs in Kaneohe Bay, Hawaii. Mar Biol. DOI 10.1007/BF00391141

Leis JM (1986a) Vertical and horizontal distribution of fish larvae near coral reefs at Lizard Island, Great Barrier Reef. Mar Biol. DOI 10.1007/BF00409271

Leis JM (1986b) Epibenthic schooling by larvae of the clupeid fish Spratelloides gracilis. Jpn J Ichthyol 22:67-69

Leis JM (1991a) The pelagic stage of reef fishes: the larval biology of coral reef fishes. In: Sale PF (ed) The ecology of fishes on coral reefs. Academic, San Diego, pp 183-230

Leis JM (1991b) Vertical distribution of fish larvae in the Great Barrier Reef Lagoon, Australia. Mar Biol. DOI 10.1007/ BF01320243

Leis JM (1993) Larval fish assemblages near Indo-Pacific coral reefs. Bull Mar Sci 53:362-392

Leis JM (2002) Pacific coral-reef fishes: the implications of behaviour and ecology of larvae for biodiversity and conservation, and a reassessment of the open population paradigm. Environ Biol Fish. DOI 10.1023/A:1020096720543

Leis JM (2004) Vertical distribution behaviour and its spatial variation in late-stage larvae of coral-reef fishes during the day. Mar Fresh Behav Physiol. DOI 10.1080/ 10236240410001705761

Leis JM (2006) Are larvae of demersal fishes plankton or nekton? Adv Mar Biol. DOI 10.1016/s0065-2881(06)51002-8

Leis JM, Carson-Ewart BM (1999) In situ swimming and settlement behaviour of larvae of an Indo-Pacific coral-reef fish, the coral trout Plectropomus leopardus (Pisces: Serranidae). Mar Biol. DOI 10.1007/s002270050524

Leis JM, Carson-Ewart BM (2000a) Behaviour of pelagic larvae of four coral-reef fish species in the ocean and an atoll lagoon. Coral Reefs. DOI 10.1007/s003380000115

Leis JM, Carson-Ewart BM (2000b) The larvae of Indo-Pacific coastal fishes. An identification guide to marine fish larvae. Brill, Leiden

Leis JM, McCormick MI (2002) The biology, behavior and ecology of the pelagic, larval stage of coral reef fishes. In: Sale PF (ed) Coral reef fishes: dynamics and diversity in a complex ecosystem. Academic, San Diego, pp 171-199

Leis JM, Trnski T, Doherty PJ, Dufour V (1998) Replenishment of fish populations in the enclosed lagoon of Taiaro Atoll: (Tuamotu Archipelago, French Polynesia) evidence from eggs and larvae. Coral Reefs. DOI 10.1007/s003380050085

Leis JM, Trnski T, Dufour V, Harmelin-Vivien M, Renon J-P, Galzin R (2003) Local completion of the pelagic larval stage of coastal fishes in coral-reef lagoons of the Society and Tuamotu Islands. Coral Reefs. DOI 10.1007/s00338-003-0316-3

Leis JM, Hay AC, Trnski T (2006) In situ ontogeny of behaviour in pelagic larvae of three temperate, marine, demersal fishes. Mar Biol. DOI 10.1007/s00227-005-0108-0

Lester SE, Ruttenberg BI (2005) The relationship between pelagic larval duration and range size in tropical reef fishes: a synthetic analysis. Proc R Soc B. DOI 10.1098/rspb .2004 .2985

Marliave JB (1981) Vertical migrations and larval settlement in Gibertidia sigalutes, F. Cottidae. Rapp P-v Réun 178:349-351

Marliave JB (1986) Lack of planktonic dispersal of rocky intertidal fish larvae. Trans Am Fish Soc. DOI 10.1577/15488659(1986) $115<149:$ LOPDOR > 2.0.CO;2

Martins F, Leitão P, Neves R (2002) Simulating vertical water mixing in homogeneous estuaries: the Sado estuary case. Hydrobiologia 475/476:221-227

McGowen GE (1993) Coastal ichthyoplankton assemblages, with emphasis on the southern California Bight. Bull Mar Sci 53:692-722 
Montgomery JC, Tolimieri N, Haine OS (2001) Active habitat selection by pre-settlement reef fishes. Fish Fisheries. DOI 10.1046/j.1467-2960.2001.00053.x

Mora C, Sale PF (2002) Are populations of coral reef fish open or closed? Trends Ecol Evol. DOI 10.1016/S01695347(02)02584-3

Moser HG, Smith PE (1993) Larval fish assemblages of the California Current region and their horizontal and vertical distributions across a front. Bull Mar Sci 53:645-691

Myrberg AA Jr, Fuiman LA (2002) The sensory world of coral reef fishes. In: Sale PF (ed) Coral reef fishes: dynamics and diversity in a complex ecosystem. Academic, San Diego, pp 123-148

Neilson JD, Perry RI (1990) Diel vertical migrations of marine fishes: an obligate or facultative process? Adv Mar Biol 26:115-168

Olivar MP (1990) Spatial patterns of ichthyoplankton distribution in relation to hydrographic features in the Northern Benguela region. Mar Biol. DOI 10.1007/BF02114672

Olivar MP, Sabatés A (1997) Vertical distribution of fish larvae in the north-west Mediterranean Sea in spring. Mar Biol. DOI $10.1007 / \mathrm{s} 002270050169$

Paris C, Cowen RK (2004) Direct evidence of a biophysical retention mechanism for coral reef fish larvae. Limnol Oceanogr 49:1964-1979

Petersen CGJ (1919) Our gobies (Gobiidae). From the egg to the adult stages. Rep Danish Biol Stat 26:45-66

Quignard JP (1967) L'oeuf et la larve du Labridé Symphodus (Crenilabrus) melops (Linné, 1758) influence de différents facteurs physicochimiques sur la durée du développement embryonnaire. Rev Trav Inst Pech Marit 31:355-358

Quignard JP (1968) Nouvelles données sur le problème racial chez Symphodus (Crenilabrus) cinereus (Bonnaterre, 1788).Fécondation artificielle et élevage expérimental de ce labridé. Bull Mus Natl Hist Nat 2 40:265-274

Raventós N, Macpherson E (2001) Planktonic larval duration and settlement marks on the otoliths of Mediterranean littoral fishes. Mar Biol. DOI 10.1007/s002270000535

Russell FS (1976) The eggs and planktonic stages of British marine fishes. Academic, London

Sabatés A (2004) Diel vertical distribution of fish larvae during the winter-mixing period in the northwestern Mediterranean. ICES J Mar Sci. DOI 10.1016/j.icesjms.2004.07.022

Sabatés A, Zabala M, García-Rubies A (2003) Larval fish communities in the Medes Islands Marine Reserve (north-west Mediterranean). J Plankton Res. DOI 10.1093/plankt/25.9.1035

Smith CL, Tyler JC, Stillman L (1987) Inshore ichthyoplankton: a distinctive assemblage? Bull Mar Sci 41:432-440

Somarakis S, Drakopoulos P, Filippou V (2002) Distribution and abundance of larval fish in the northern Aegean Sea-east- ern Mediterranean-in relation to early summer oceanographic conditions. J Plankton Res. DOI 10.1093/plankt/ 24.4.339

Southward AJ, Barrett RL (1983) Observations on the vertical distribution of zooplankton, including post-larval teleosts, off Plymouth in the presence of a thermocline and a chlorophyll-dense layer. J Plankton Res 5:599-618

Sponaugle S, Cowen RK (1996) Nearshore patterns of coral reef fish larval supply to Barbados, West Indies. Mar Ecol Prog Ser 133:13-28

Sponaugle S, Cowen RK, Shanks A, Morgan SG, Leis JM, Pineda J, Boehlert GW, Kingsford MJ, Lindeman KC, Grimes C, Munro JL (2002) Predicting self-recruitment in marine populations: biophysical correlates and mechanisms. Bull Mar Sci 70:341-375

Sponaugle S, Fortuna J, Grorud K, Lee T (2003) Dynamics of larval fish assemblages over a shallow coral reef in the Florida Keys. Mar Biol. DOI 10.1007/s00227-003-0159-y

Steffe A (1990) Epibenthic schooling by larvae of the atherinid fish Leptatherina presbyteroides: an effective mechanism for position maintenance. Jpn J Ichthyol 36:488-491

Swearer SE, Caselle JE, Lea DW, Warner RR (1999) Larval retention and recruitment in an island population of a coralreef fish. Nature. DOI 10.1038/45533

Swearer SE, Shima JS, Hellberg ME, Thorrold SR, Jones GP, Robertson DR, Morgan SG, Selkoe KA, Ruiz GM, Warner RR (2002) Evidence of self-recruitment in demersal marine populations. Bull Mar Sci 70:251-271

Taylor MS, Hellberg ME (2003) Genetic evidence for local retention of pelagic larvae in a Caribbean reef fish. Science. DOI 10.1126/science. 1079365

Thresher RE (1984) Reproduction in reef fishes. T.F.H. Publications, New Jersey

Thresher RE, Colin PL, Bell LJ (1989) Planktonic duration, distribution and population structure of western and central Pacific damselfishes (Pomacentridae). Copeia 1989:420-434

Tilney RL, Nelson G, Radloff SE, Buxton CD (1996) Ichthyoplankton distribution and dispersal in the Tsitsikamma National Park Marine Reserve, South Africa. S Afr J Mar Sci 17:1-14

Vélez JA, Watson W, Arntz W, Wolff M, Schnack-Schiel SB (2005) Larval fish assemblages in Independencia Bay, Pisco, Peru: temporal and spatial relationships. Mar Biol. DOI 10.1007/s00227-004-0535-Z

Victor BC, Wellington GM (2000) Endemism and the pelagic larval duration of reef fishes in the eastern Pacific Ocean. Mar Ecol Prog Ser 205:241-248

Wilson DT (2001) Patterns of replenishment of coral-reef fishes in the nearshore waters of the San Blas Archipelago, Caribbean Panama. Mar Biol. DOI 10.1007/s002270100609 